\title{
Use of the space by the opossum Didelphis aurita Wied-Newied (Mammalia, Marsupialia) in a mixed forest fragment of southern Brazil
}

\author{
Nilton Carlos Cáceres ${ }^{1}$ \\ ${ }^{1}$ Departamento de Biociências, Universidade Federal do Mato Grosso do Sul. Caixa Postal 051, 79200-000 Aquidauana, \\ Mato Grosso do Sul, Brasil. E-mail: nc_caceres@hotmail.com
}

\begin{abstract}
Use of the space by the opossum Didelphis aurita Wied-Newied, 1826 (Mammalia, Marsupialia) in a mixed forest fragment of southern Brazil. The space use of the marsupial Didelphis aurita was studied in a forest fragment of southern Brazil from February 1995 to January 1996. The method used was the 'distribution utilization' in which each trap was set in $38 \times 38$ m quadrats. Captures of each marked individual in each point give information on its habitat use. Food availability was searched and compared to the habitat utilization and to the food consumption of opossums. Distribution patterns of captures (aggregated to random) and spatial overlap between individuals were searched. Results showed aggregated distributions of individuals, particularly females, in the fragment. Females used exclusively the fragment during the drier season. Opossums tend to not choose the sites with highest food availability to establish home ranges. Spatial overlap was usually low between forest resident and neighbouring resident females, but much lower during the breeding season (only forest resident females) in an apparently pattern of territoriality. Hence, core areas of females decreased in size during the breeding season. Males probably searched primarily for mates during the breeding season being less opportunistic than females in feeding habits, yet their space use did not correlate to food consumption.
\end{abstract}

KEY WORDS. food availability, habitat fragmentation, home range, individual interaction, territorial behaviour.

The use of the space by animals may be affected by food availability and individual interactions. Female small mammals are usually dependent on resources available (particularly food) in one area, and are less mobile than males. Movements of males often depend on female movements (OstFeld 1990, WolfF 1993, KREBS \& DAVIS 1996) preponderantly in the reproductive season. Therefore, females are often territorial, defending (actively or not) certain resource rich sites from their conspecifics, whereas males usually are non-territorial. However, there are exceptions such as territorial males defending spatially clumped females in voles (OstFeld 1990). As some females are more territorial during the period of higher food availability, it has been suggested that territoriality did not evolve to increase food availability but to avoid offspring mortality by conspecifics (WolfF 1993).

Space use patterns may also indicate the social system of the species. When the home range of a nonterritorial male overlaps with those of several territorial females, the social system of such species is probably promiscuous. When a territorial male overlaps with several nonterritorial females, the social system is probably polygynous, and when a male overlaps with a single female, the system is likely to be monogamous (Ostreld 1990).

Use of space has been studied in a few genera of didelphid marsupials: Didelphis Linnaeus, 1758 (e.g. Sunquist et al. 1987, Ryser 1992, Hossler et al. 1994, Cáceres \& Monteiro-Filho 2001),
Philander Tiedemann, 1808 (Charles-Dominique 1983), Lutreolina Thomas, 1910 (Monteiro-Filho \& Dias 1990), Caluromys J.A. Allen, 1900 (Atramentowicz 1982, Julien-LafERrière 1995, 1999) and Micoureus Lesson, 1842 (Pires \& Fernandez 1999). However, the data are scarce for even those species, which have wide ranges in the Neotropics (EMmONs \& FEer 1997). In this study, the effects of food availability on patterns of space use by the opossum, Didelphis aurita Wied-Newied, 1826 (Didelphidae), as well as its general pattern of space use are investigated.

\section{MATERIAL AND METHODS}

\section{Study area}

The study area was covered by a mixed (or Araucaria) ombrophyllous forest fragment in an urban environment (Curitiba municipality) in southern Brazil. The fragment was covered mainly by disturbed secondary forest, was nearly 5 ha in area, and had an irregular form (Fig. 1). An unpolluted creek had its source in the fragment, but it was polluted by a sewerage when it left the fragment. The fragment was surrounded by barren lands, gardens, residences and roads.

The region is subject to two indistinct seasons: the drier and cold season (April to August) and the rainy and warm 
season (September to March). The mean annual rainfall ranges around $1350 \mathrm{~mm}$ and the annual temperature in the region is $17^{\circ} \mathrm{C}$, with higher temperatures occurring during the rainy season (MAACK 1981)

\section{Trapping}

The study area was divided in 30 square $(38 \times 38 \mathrm{~m})$ plots. Each of these plots had a $40 \times 20 \times 20 \mathrm{~cm}$ trap placed on the ground as near as possible to the quadrat center, following an irregular grid pattern. Twenty-eight traps were placed inside the forest fragment and two were placed outside it, in open areas (Fig. 1).

The trapping period was from February 1995 to January 1996 when all traps were used once a week by opening them in the afternoon and checking them the following morning. The bait used was banana mixed with cod liver oil and peanut butter. Opossums trapped were monthly weighed, marked with holes in the ear at first capture, sexed, aged (following TyNDALEBiscoe \& Mackenzie 1976), and released. Age classes were defined as young (p3M2), subadult (P3M3) and adult (P3M4) (see also CÁceres \& Monteiro-Filho 1999).

Based on data on reproduction of $D$. aurita available for this area (CÁCERES \& MONTEIRO-FILHO 1997), trapping periods were classified as those belonging to the non-reproductive season (NRS) (February to June) and those to the reproductive season (RS) (July to January).

\section{Home range}

To obtain more accurate home range sizes, only those individuals trapped five times or more were used. Those individuals trapped frequently $(\mathrm{N}>9$ and at least one capture per month) in the fragment, during one or both seasons monitored, were considered as "forest resident" opossums. Those occasionally trapped in both seasons were primarily accounted as neighbouring residents, although those trapped only once were considered as migrants. Using the Distribution Utilization method (SAmuel et al. 1985), the home range area was considered as the total plots used by an individual (with each plot $=38 \mathrm{x}$ $38 \mathrm{~m}$ ), and the home range size was evaluated by counting how many plots were used. Home ranges of infrequently trapped individuals $(\mathrm{N}>5,<10)$, containing two or more used plots separated by apparently unused plots, were measured by adding these latter ones in the calculation of the home range area.

In order to calculate accurate core areas in the home range, only individuals with more than 10 captures in one season were analysed. Core areas were considered as those plots significantly more used than the expected rate from an uniform pattern in a home range area (SAMUel et al. 1985), that is, expected rates will be the number of captures of an individual divided by the total plots in its home range. In order to verify if the utilization of the study area by opossums differed from the uniform distribution, the one sample Kolmogorov-Smirnov $D$ test (ZAR 1984) was used. In addition, to test whether the distribution of captures of an individual was random or aggregated, the Index of Dispersion (ID) test was applied, which was supplemented by a two tailed Chi-square test to detected significant levels of dispersion (KreBs 1989). The ID is obtained by the division of the observed variance by the observed mean captures per plot of an individual regarding all plots in study area $(\mathrm{N}=30)$, and results more than 1.0 reveal aggregated distributions (KREBS 1989).

Revista Brasileira de Zoologia 20 (2): 315-322, junho 2003

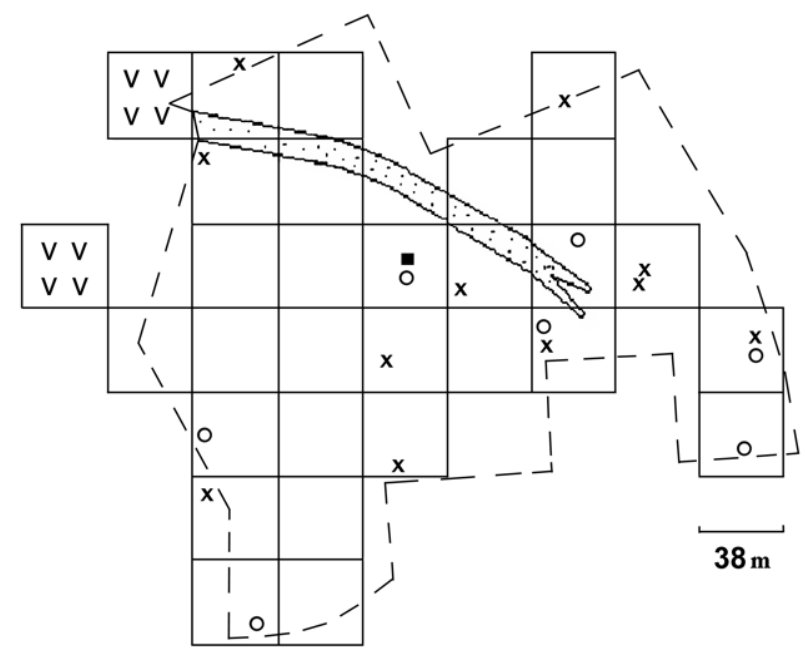

Fig. 1. Study area showing its irregular boundaries, its division in quadrats (each one with a trap) for the study and the fruiting plant availability for opossums between February 1995 and January 1996. All quadrats (4.3 ha) represent quite the entire area of the fragment ( $5 \mathrm{ha}$ ). Only the two quadrats located at left ( $V \mathrm{~V})$ show open areas and all remaining quadrats are located inside the Araucarian forest fragment. Dotted area indicates a creek. Fruiting plants are: (ם) Solanum swartzianum, (O) S. granulosoleprosum, and $(\times)$ S. sanctaecathariane.

\section{Space use and food availability}

To investigate relationships between the plot utilisation by individuals and the availability of fruiting plants $(\mathrm{N}=3$ species) in the study area, their numbers were evaluated inside and outside home ranges and differences found were tested using the likelihood ratio $G$ test (ZAR 1984).

The use of plots containing portions of the creek (see Fig. 1) by opossums was evaluated by comparing the observed rate, or plot utilisation, with an uniform, expected, rate of utilisation, which was the total number of creek-plots $(\mathrm{N}=8)$ divided by all plots in the study area $(\mathrm{N}=30)$, resulting in an expected value of $0.3(30 \%)$. The creek, located in a 3 to $6 \mathrm{~m}$ depression of the relief and with a dominance of the shrub Piper gaudichaudianum and ferns, was a good additional source of food for opossums such as crabs (e.g. Aegla sp.), besides the source of water and humidity. The $G$ test (ZAR 1984) was used to determine whether differences between the utilization of creek-plots was significantly different from the utilization of non-creek plots, based also on the number plots used. In addition, minimal distances between each capture and the creek were measured for each forest resident individual, and these results were tested (one test per individual) through the one sample Kolmogorov-Smirnov $D$ test in order to test for significant differences from the uniform and the exponential distributions (ZAR 1984).

In order to search if there was a relationship between local food availability in the home range of opossums and their food consumption, that is, the frequency of occurrence of the respective items in their feces (see CácEREs \& Monteiro-FilHo 2001, 
for detailed methods), Spearman $R$ correlation tests (ZAR 1984) were used (being individual as an unit). Correlations were performed by analysing food availability (that is, fruiting Solanaceous plants or crabs) in total home ranges of all individuals with five or more captures $(5>)$, total home ranges of resident females only (excluding males) $(5>)$, core areas only (excluding non-core areas) of all individuals $(5>)$, and each central plot plus the eight adjacent plots. If there were parameters of food availability well correlated between themselves, these were excluded from the test because the assumption of independence of plant distribution. Food availability was intended as: (a) availability of fruiting plants ( $\mathrm{N}=3$ flesh fruit species) for which the expected occurrence in a home range would be the respective amount of seeds in feces of each opossum, and (b) availability of creek areas for which the expected occurrence in a home range would be the frequency of crab remaining in feces. These last considerations are possible by assuming the hypothesis that opossums are opportunists when foraging (ATRAMENTOWICZ 1982). All home ranges were searched and calculated in synchronization to the time of each food item availability (several months in general). Whether correlations were positive and significant after sequential Bonferroni correction (SOKAL \& ROHLF 1995), this will imply that individuals involved are truly opportunists in their respective home ranges.

\section{Spatial overlap}

The spatial overlap between individuals was measured by counting those plots shared by each pair of opossums. For these calculations, core areas were considered as well as the total home range areas for each individual. The Horn Index of Niche Overlap (Krebs 1989) multiplied by 100 gave the percentage of area overlap between individuals.

\section{RESULTS}

\section{Individual accounts}

A total of 18 individuals of $D$. aurita was trapped during the 1 year study, totalising 190 captures. Only four females (numbers 1, 4, 6 and 7) were responsible for $63 \%$ of all captures, being trapped for at least one season and considered as forest resident individuals in the fragment.

Female 6 weighted more than other resident females during the non-reproductive season (NRS) (Tab. I). It was adult (age class 5) at the start of this season while another forest, or neighbouring, resident females were young (age class 3 ) at their first captures. However, females 1 and 7 developed to the adult stage at the end of the same NRS (Tab. I).

At the start of the reproductive season (RS), three out of four forest resident females were adults and had pouch young in August. Their weights increased in relation to the NRS and the difference in body size among them decreased (Tab. I).

Neighbouring resident females, with less than 10 total captures, were only one young individual (female 3) during the NRS and three adults (females 8, 10, and 18) during the RS. From those, females 8 and 10 had young in the RS. The migrant female 14 also had young in the RS. Only one female, out of eight, had not young $(12,5 \%)$ during the RS (Tab. I).

Only two males were considered as forest residents because the remaining individuals $(\mathrm{N}=5)$ was infrequently trapped in the area, being considered as migrants or neighbouring residents, that is, individuals established in neighbouring areas but with occasional incursions inside the fragment. The two forest resident males were heavier than any of the females (Tab. I).

\section{Spatial use of the fragment}

All four forest resident females showed aggregated distributions of captures in the study area (Tab. II) $(\mathrm{p}<0.01, \mathrm{D}$ $>0.330$, Kolmogorov-Smirnov test). These females used exclusively the fragment in the NRS $(\mathrm{N}=4)$ and males appeared in the area mainly during the $\mathrm{RS}(\mathrm{N}=6$ from a total of 7$)$. Female home range sizes in the fragment ranged from 0.6 to 1.7 ha in the NRS but from 0.6 to 1.3 ha in the RS (Tab. II). These differences between home ranges of one season to another were not significant $(\mathrm{p}>0.60, \mathrm{U}=10.0, \mathrm{~N}=10)$. However, home range sizes of males (2.3-2.7 ha) were larger than those of females $(\mathrm{p}=0.05, \mathrm{U}=0.0, \mathrm{~N}=7)$ during the RS. The home range of the neighbouring resident female 18 was the only one to include areas outside the fragment. However, trapping in open areas was limited. All neighbouring resident females had peripheral home ranges in the forest fragment (in edges) during the two seasons (Fig. 2).

The older and heavier female in the NRS (F 6) had the largest home range while the younger and lighter ones had the smaller home ranges (Tab. II). In the RS, home ranges of forest resident females were similar in size among themselves but larger than those of neighbouring resident females, at least in the forest fragment (Tab. II, Fig. 2).

Core areas of forest resident females were larger in the NRS and ranged from 0.4 to 0.7 ha, whereas during the RS, they were smaller and ranged from 0.3 to 0.4 ha (Tab. II). These differences between the two seasons were significant $(\mathrm{p}<0.05$, $\mathrm{U}=0.5, \mathrm{~N}=7$ )

The first capture of the resident female 1 (young - class 3 - at this stage) was not considered as a location included in its home range because it was located in an area far from its established home range (approximately $150 \mathrm{~m}$ ) and, thus, was considered to be a dispersive movement toward its future home range (Fig. 2).

\section{Spatial overlap}

There was a decrease in the spatial overlap regarding home range area of resident females from the NRS (averaging $19 \%$, Standard Deviation $=11, \mathrm{~N}=5)$ to the RS $(12 \%, \mathrm{SD}=13$, $\mathrm{N}=6$ ). The mean overlap between core areas of forest resident females during the NRS was $15 \%(\mathrm{SD}=14, \mathrm{~N}=4)$, whereas during the RS was only $6 \%(\mathrm{SD}=10, \mathrm{~N}=6)$, now including two neighbouring females most trapped. The two forest resident males sampled showed high spatial overlap (77\%) and also with forest resident and neighbouring females during the RS (Fig. 2). Among forest resident females, shared core areas were those near the creek or rich in fruiting plants often consumed by opossums (Figs 1 and 2 see below).

\section{Food availability and resource utilization}

\section{Flesh Fruits}

There were not significant differences between the number of fruiting plants inside and outside home ranges of opossums ( $\mathrm{p}>0.05 ; G$ test), except for female $6(\mathrm{p}<0.05, \mathrm{~N}=$ 25 fruiting plants) and male 11 home ranges ( $\mathrm{p}<0.01 ; \mathrm{N}=29$ fruiting plants). 
Table I. Weight (g) and age at first trapping of resident and transient individuals of Didelphis aurita in a forest fragment of southern Brazil. $\left({ }^{\star}\right)$ Females with litters in the reproductive season; ${ }^{* *}$ ) adult female not in reproduction; $(\mathrm{N})$ number of times weight was registered per individual. Age classes follow TYNDALE-BISCOE \& MACKENZIE (1976). Weight variation is given in Standard Deviation. (FR) Forest fragment resident, (NR) neighbouring resident, (M) migrant, only one capture.

\begin{tabular}{|c|c|c|c|c|c|c|c|}
\hline \multirow{2}{*}{ Individual } & \multicolumn{3}{|c|}{ Non-reproductive season } & \multicolumn{3}{|c|}{ Reproductive season } & \multirow{2}{*}{ Spatial use } \\
\hline & Age class & Weight & $\mathrm{N}$ & Age class & Weight & $\mathrm{N}$ & \\
\hline $\mathrm{F} 1$ * & Young & $902 \pm 105$ & 5 & Adult & $1095 \pm 42$ & 2 & FR \\
\hline M 2 & Young & $1135 \pm 530$ & 2 & - & - & - & NR \\
\hline F 3 & Young & $915 \pm 35$ & 2 & - & - & - & NR \\
\hline F 4 & Young & $865 \pm 203$ & 3 & Subadult & 875 & 1 & FR \\
\hline $\mathrm{F} 5$ ** & Adult & 1375 & 1 & - & - & - & M \\
\hline $\mathrm{F} 6$ * & Adult & $1494 \pm 132$ & 4 & Adult & $1397 \pm 44$ & 4 & FR \\
\hline $\mathrm{F} 7$ * & Young & $807 \pm 169$ & 5 & Adult & $995 \pm 121$ & 6 & FR \\
\hline $\mathrm{F} 8$ * & Adult & 1150 & 1 & Adult & $1191 \pm 166$ & 3 & NR \\
\hline M 9 & - & - & - & Adult & $1865 \pm 198$ & 2 & NR \\
\hline $\mathrm{F} 10$ * & - & - & - & Adult & 1190 & 1 & NR \\
\hline M 11 & - & - & - & Adult & $1642 \pm 124$ & 3 & FR \\
\hline M 12 & - & - & - & Adult & 1645 & 1 & FR \\
\hline M 13 & - & - & - & Adult & $1880 \pm 42$ & 2 & NR \\
\hline $\mathrm{F} 14$ * & - & - & - & Adult & 1120 & 1 & M \\
\hline M 15 & - & - & - & Adult & 1555 & 1 & NR \\
\hline M 16 & - & - & - & Adult & 1825 & 1 & M \\
\hline $\mathrm{F} 17$ * & - & - & - & Adult & 1205 & 1 & NR \\
\hline $\mathrm{F} 18$ ** & - & - & - & Adult & $1210 \pm 106$ & 2 & NR \\
\hline
\end{tabular}

Table II. Spatial use of opossums (Didelphis aurita) in a 5 ha-Araucarian forest fragment of Curitiba, Southern Brazil. Only individuals with at least 5 captures are shown. $\mathrm{N}$ is the number of total captures. \% Core is the percentage of core plots in relation to the total home range plots of one individual. Numbers in parentheses indicate the distance $(\mathrm{m})$ between core areas of one individual. $S$ is spatial use where FR is forest resident and NR is neighbouring resident. (AG) Aggregated distribution of captures. Traces indicate no data.

\begin{tabular}{|c|c|c|c|c|c|c|c|c|c|}
\hline \multirow{3}{*}{ Individuals } & \multirow{3}{*}{$S$} & \multirow{3}{*}{$N$} & \multirow{3}{*}{$\begin{array}{l}\text { Distribution } \\
\text { of captures }\end{array}$} & \multicolumn{6}{|c|}{ Home range size } \\
\hline & & & & \multicolumn{3}{|c|}{ Non-reproductive season } & \multicolumn{3}{|c|}{ Reproductive season } \\
\hline & & & & Total (ha) & Core (ha) & $\%$ Core & Total (ha) & Core (ha) & $\%$ Core \\
\hline F 1 & FR & 31 & AG & 1.16 & 0.72 & 62.1 & 0.87 & 0.29 & 33.3 \\
\hline F 3 & NR & 5 & - & 0.58 & - & - & - & - & - \\
\hline F 4 & FR & 15 & AG & 0.58 & 0.43 & 75.0 & - & - & - \\
\hline F 6 & $\mathrm{FR}$ & 34 & $A G$ & 1.73 & 0.72 & 41.6 & 1.30 & 0.43 & 33.1 \\
\hline F 7 & FR & 39 & AG & 1.16 & 0.43 & 37.1 & 1.01 & 0.29 & 28.7 \\
\hline F 8 & NR & 6 & - & - & - & - & 0.58 & - & - \\
\hline F 18 & NR & 5 & - & - & - & - & 0.58 & - & - \\
\hline M 11 & NR & 8 & - & - & - & - & 2.74 & - & - \\
\hline M 12 & NR & 6 & - & - & - & - & 2.31 & - & - \\
\hline
\end{tabular}

Revista Brasileira de Zoologia 20 (2): 315-322, junho 2003 

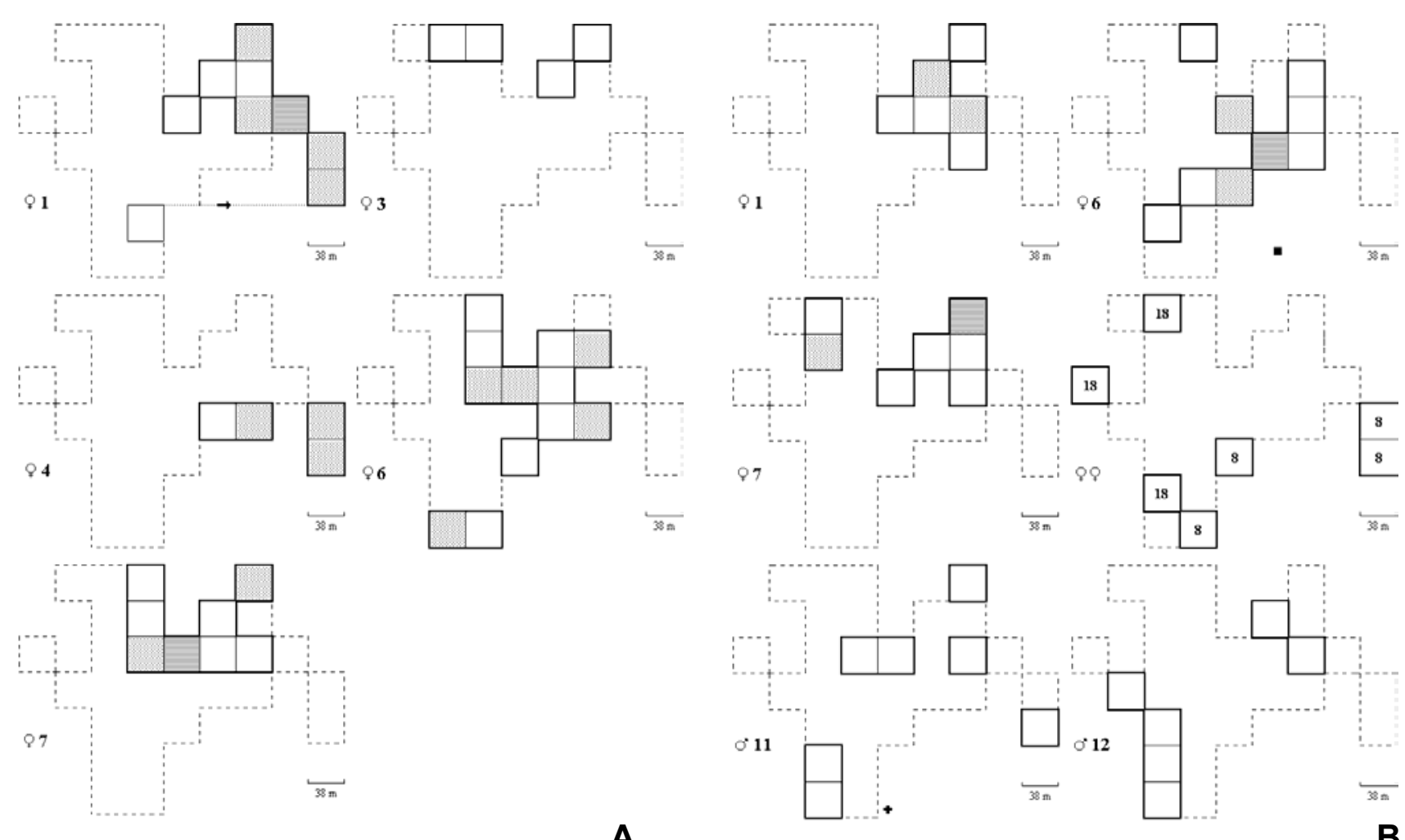

Fig. 2. Home ranges and core areas of the opossum Didelphis aurita seen by the distribution utilization method in a small forest fragment area of southern Brazil during all study time. In white (non-core) quadrats: captures $(c)=$ than the mean captures ( $\left.c_{m}\right)$; in light dotted quadrats: $\mathrm{c}_{\mathrm{m}}<\mathrm{c}<2 \mathrm{c}_{\mathrm{m}}$; in shadow dotted quadrats: $2 \mathrm{c}_{\mathrm{m}}<\mathrm{c}<3 \mathrm{c}_{\mathrm{m}}$; in hatched quadrats: $3 \mathrm{c}_{\mathrm{m}}<\mathrm{c}<4 \mathrm{c}_{\mathrm{m}}$. Numbers indicate the register animal numbers; the cross (+) indicates a tree den of male 11; the square indicates a point in which female 6 was seen feeding on rubbish being pursued by a non-identified adult male in the reproductive season (RS). Female 3 was trapped in the non-RS while females 8 and 18 and males during the RS. Dashed lines are the boundaries of the study area.

When food consumption seen from fecal analysis was compared to the food availability in home ranges, some significant correlations were detected (Tab. III). The consumption of Solanum sanctaecatharinae fruits by opossums was significantly related to the number of fruiting $S$. sanctaecatharinae plants located inside the entire home range of all individuals ( $\mathrm{p}<0.01, \mathrm{R}=0.80, \mathrm{~N}=9$ ), and also for female home ranges only $(\mathrm{p}<0.05, \mathrm{R}=0.78, \mathrm{~N}=7)$, excluding males. This last result repeated for $S$. granulosoleprosum and for crabs (Tab. III). No fruit or crab availability had significant correlation between themselves. However, only the comparisons [ $S$. sanctaecatharinae $\mathrm{x}$ total home range of all individuals] and [crabs $\mathrm{x}$ total home ranges excluding those of males] were significant after Bonferroni correction (Tab. III). Any way, there were general trends for feeding habits of females be correlated to food availability in the scale of total home ranges but not considering males (except maybe for $S$. sanctaecatharinae fruits), and in a scale greater than a $38 \times 38$ m plot. In summary, when all individuals were pooled in a correlation analysis (each individual as units; Tab. III), fruiting plant availability in each home range revealed close relation to consumption by opossums, preponderantly females. These relationships pointed out reasonable degree of opportunism behavior for opossums, in which they often fed according to the global resource availability in their respective home ranges.

\section{Crabs in the creek}

Forest resident females showed higher year round utilization rates of plots containing portions of the creek (47 to $50 \%$ on average) than expected $(30 \%)$, regarding the proportion of creek plots in their home range. The utilization of creek areas by them was similar for core areas $(50 \%$, Standard Deviation $=14, \mathrm{~N}=4)$ and whole home range areas $(47 \%, \mathrm{SD}=$ $16, \mathrm{~N}=4$ ). However, for all individuals including neighbouring residents, the creek utilization was similar to the expected rate for the study area $(33 \%, \mathrm{SD}=22, \mathrm{~N}=9)$.

Distances between captures and the creek indicated that forest resident individuals tended to preferentially forage around the creek. All individual distances thus differed significantly from the expected uniform distribution $(\mathrm{p}<0.01$; $\mathrm{D}>0.290$ ), but did not differ from the expected exponential distribution for all forest resident females ( $p>0.05, \mathrm{D}<0.290)$, showing, in general, a high utilization of sites near the creek and a minor utilization of sites distant from the creek (Fig. 3).

Revista Brasileira de Zoologia 20 (2): 315-322, junho 2003 
Table III. Relationships between food consumption by opossums and food availability in a forest fragment of southern Brazil during one year-study. Food consumption was searched by investigating the presence of seeds or crab remains in feces of opossums. The food availability was measured by counting fruiting plants or creek areas (for crabs) in each plot $(38 \times 38 \mathrm{~m})$ regarding home ranges of individuals (as units). $\mathrm{N}_{\mathrm{f}}$ is the total number of occurrence of food remains (seeds or crabs) in feces of opossums. $\mathrm{N}_{\mathrm{i}}$ is the number of individuals of Didelphis aurita analysed. Range is the number of different fruiting plants (/area/individual) or \% of creek plots registered in total plots used. (NS) non-significant correlation. Only animals trapped during the period of fructification of one plant were used. $\left({ }^{*}\right) \mathrm{p}$ values significant after Bonferroni correction (SOKAL \& ROHLF 1995).

\begin{tabular}{|c|c|c|c|c|c|}
\hline Food items & $N_{f}$ & Range & $\mathrm{N}_{\mathrm{i}}$ & $\mathrm{R}$ & $\mathrm{p}$ \\
\hline Solanum sanctaecatharinae Dunal & 33 & & & & \\
\hline Total home range of all individuals & & $1-4$ & 9 & 0.80 & $<0.01^{*}$ \\
\hline Females excluding males & & $2-4$ & 7 & 0.78 & $<0.05$ \\
\hline Core areas of females & & $1-3$ & 4 & 0.71 & NS \\
\hline Plots plus adjacent ones & & $3-27$ & 9 & 0.50 & NS \\
\hline Solanum granulosoleprosum Dunal & 19 & & & & \\
\hline Total home range of all individuals & & $0-4$ & 9 & 0.22 & NS \\
\hline Females excluding males & & $0-3$ & 7 & 0.76 & $<0.05$ \\
\hline Core areas of females & & $0-1$ & 4 & 0.27 & NS \\
\hline Plots plus adjacent ones & & $2-14$ & 9 & 0.48 & NS \\
\hline Solanum swartzianum Roem. \& Schult. & 10 & & & & \\
\hline Total home range of all individuals & & $0-1$ & 6 & 0.40 & NS \\
\hline Females excluding males & & $0-1$ & 4 & 0.89 & NS \\
\hline Core areas of females & & - & - & - & - \\
\hline Plots plus adjacent ones & & $0-3$ & 6 & 0.89 & $<0.02$ \\
\hline Crabs from the creek & 41 & & & & \\
\hline Total home range of all individuals & & $0-75$ & 9 & 0.61 & NS \\
\hline Females excluding males & & $0-75$ & 7 & 0.91 & $<0.01^{*}$ \\
\hline Core areas of females & & $33-67$ & 4 & 0.71 & NS \\
\hline Plots plus adjacent ones & & $10-63$ & 9 & 0.65 & NS \\
\hline
\end{tabular}

\section{DISCUSSION}

\section{Spatial interactions in the forest fragment: females}

Didelphis aurita clearly established their home ranges in aggregated patterns, with low, sometimes reasonable, overlapping among them in the forest fragment, even when young, and maintained home ranges until the start of the reproductive season. Before this phase when they were younger, it is most probable that they had shown an exploratory and dispersing behaviour, searching for suitable areas to set their home ranges (COCKBurn et al. 1985, HossLer et al. 1994, JULIEN-LAFERRIÈre 1995), as was seen for a female in the present study. A clear pattern of space use was the predominance of an older and weighter female in most, central, areas of the fragment during NRS, leading younger for surrounding areas of the fragment. However, this pattern was changed during the RS, when home
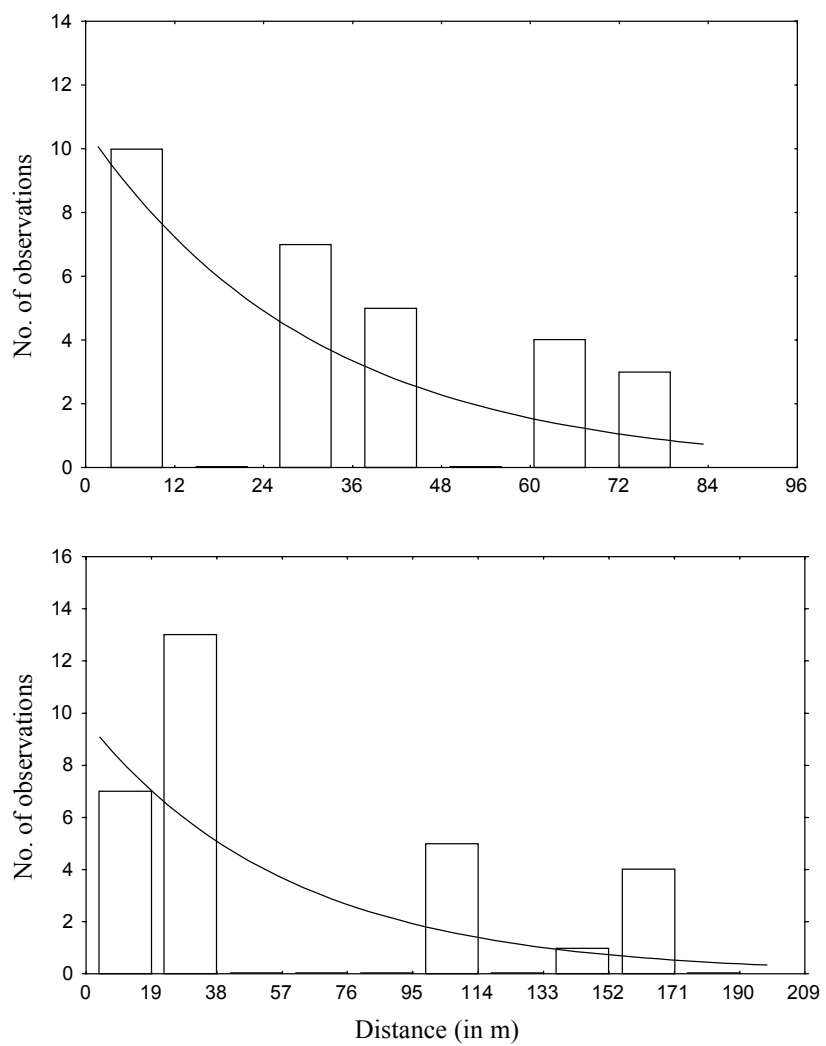

Fig. 3. Distribution of captures of two females (\# 1 above and \# 6 below) of Didelphis aurita in function of the distance from the creek in the forest fragment. The data for both opossums did not differ significantly from the expected exponential functions (fitted in the graphs) ( $p>0.05$; one sample Kolmogorov-Smirnov test).

range areas and body mass of females were similar among them, having occurred a general mass increase in younger individuals. In fact, there is a positive relationship between mass and home range size in this species (CÁCERES \& MonTeIro-Filho 2001).

Another fact is that neighbouring females tended to not displace forest resident females from the fragment, using always peripheral areas (e.g. females 3,8 and 18) more distant from the creek. This pattern of female home ranges well fixed in certain portions of an area, with few overlapping areas and without great seasonal changes, is new for Didelphis, yet it is commonly known as a nomadic species (HuNSAKER 1977, GeNTILE \& Cerqueira 1995, Julien-Laferrière 1995, Gentile et al. 1997). Nonetheless, fixed areas were already reported for female Didelphis (Cajal 1981, Sunquist et al. 1987, Ryser 1992, 1995).

These individual interactions gave directions to determine the number of individuals resident in the fragment studied, which was space limited. If there were no type of area defence by resident females (aggonistic behaviour, feces, scent marks or simple presence of the individual - KALFMANN 1983), neighbouring resident females would have displaced forest resident ones or established durable home ranges in the center of the fragment, facts that did not occur in the forest fragment.

Revista Brasileira de Zoologia 20 (2): 315-322, junho 2003 
Females apparently tolerate themselves in a certain degree in the fragment, as was seen through overlapping in home ranges and even on sites more used (core areas and near the creek), and as was reported by Ryser (1995) for D. virginiana (Kerr, 1892) (Didelphidae). Neighbouring resident female $D$. aurita appeared to avoid contact to forest resident females here, but this evidence was not well discernible as currently occur for eutherians (OsTFELD 1990). However, territoriality for didelphid marsupials have been found (FLEMING 1972, NiTIKMAN \& Mares 1987, Pires \& Fernandez 1999), including strong evidence for Didelphis (RYSER 1995).

\section{Sex dependence of food resources}

Females in the NRS showed larger core areas, as similarly seen for C. philander (Linnaeus, 1758) (Didelphidae) in French Guiana (JULIEN-LAFERRIÈRE 1995), which could be related to the low food availability, that decrease in the winter (at least for fruits; CÁCEREs et al. 1999), leading individuals to forage intensively for wider areas during this time (see C. philander in Charles-Dominique 1983). Furthermore, this was seen for Marmosa robinsoni Bangs, 1898, in which patchy food richer areas influenced movements of such species (AUGUST 1984).

Tropical forests show patterns of higher seasonal food availability in the wet season (SMithe 1970, Foster 1982, Bergallo $\&$ Magnusson 1999) that occur synchronously to the main reproductive season of opossums (JULIEN-LAFERRIÈre \& ATRAMENTOWICZ 1990). According to this, female D. aurita should certify food resources for reproduction during this time, which is suggested by the decrease of spatial overlap and core areas. Exclusive areas of reproduction, or feeding (evidence in JuLIENLAFERRIÈRE 1995), were already reported for female marsupials such as Didelphis (Hossler et al. 1994, RYSER 1992, 1995). Although opossums are generalist feeders (ATRAMENTOWICZ 1988, CÁCERES \& MonTeiro-Filho 2001), apparently they would defend an area for resources other than food such as microhabitat (see HOSSLER et al. 1994).

Female $D$. aurita primarily would not have reasons to set home ranges based only on food availability during the breeding season (most individuals did not set home ranges in so good fruiting plant areas), yet food resources are more abundant during this time. Through correlation analysis, females revealed as opportunist feeders on some flesh fruits, particularly those important in their diets (CÁCERES \& MONTEIROFILHO 2001), and on crabs available in their home ranges (preferring sites with creek portions), which shows that animals feed in proportion to the food availability in their home ranges. Thus, what other factors determinate space distribution of individuals in an area are not subjects to the present study. The study of individual interactions among opossums, as made by Holmes (1991), maybe will contribute to elucidate spatial patterns of female $D$. aurita.

Male D. aurita appear to left food resources at a secondary level in the fragment, that is, they did not feed on resources at the same scale of their availability, and probably placed mates at a first level, yet they only appeared in the fragment during the breeding season, when resident females were fertilized. Males of some didelphid marsupials are thought to search primarily for mates (ATRAMENTOWICZ 1982, RYSER 1992) and will compete for oestrous females with other males in the breeding season (SUNQUIST et al. 1987, RYSER 1992). This space use pattern, different between sexes, is often found in mammals (KALFMANN 1983), particularly those small ones such as murid rodents
(OstFeld 1990, Magnusson et al. 1995).

\section{Home range determination}

The present data suggest that female $D$. aurita avoid on each other at a some degree, as occurred among forest residents and for neighbouring females that clearly occupied peripheral areas in the fragment. Food was probably a secondary reason for home range determination yet females were opportunist feeding, consuming resources proportionally to their availability in home ranges.

\section{ACKNOWLEDGEMENTS}

I am in debt with D. Julien-Laferrière, P. Charles-Dominique, W.E. Magnusson, E.L.A. Monteiro-Filho, F.D. Avila Pires and one anonymous referees who carefully read and commented on the manuscript. Valeriano M. Cáceres-Júnior helped in the field work. Sandro M. Silva and Osmar S. Ribas helped in the plant identifications. I also thank the Companhia Paranaense de Energia (COPEL), the Curso de Pós-Graduação em Zoologia at the Universidade Federal do Paraná, and the Brazilian Councils for Research and Improvement, CNPq and CAPES, for material support, research, administration facilities, and grants, consecutively.

\section{REFERENCES}

Atramentowicz, M. 1982. Influence du millieu sur l'activité locomotrice et la reproduction de Caluromys philander L. Revue d'Ecologie Terre et la Vie, Paris, 36: 373-395.

Atramentowicz, M. 1988. La frugivorie opportuniste de trois marsupiaux didelphidés de Guyane. Revue d'Ecologie Terre et la Vie, Paris, 43: 47-57.

August, P.V. 1984. Population ecology of small mammals in the llanos of Venezuela. Special Publications of Museum Texas Tech University, Lubbook, 22: 71-104.

Bergallo, H.G. \& W.E. Magnusson. 1999. Effects of climate and food availability on four rodent species in southeastern Brazil. Journal of Mammalogy, Provo, 80: 472-486.

CÁceres, N.C.; V.A.O. Dittrich \& E.L.A. Monteiro-Filho. 1999. Fruit consumption, distance of seed dispersal and germination of Solanaceous plants ingested by the common opossum (Didelphis aurita) in southern Brazil. Revue d'Ecologie Terre et la Vie, Paris, 54: 225-234.

Cáceres, N.C. \& E.L.A. Monteiro-Filho. 1997. Reproductive biology of the common opossum, Didelphis marsupialis (Mammalia: Marsupialia), in southern Brazil. Brenesia, San José, 47-48: 117-122.

1999. Tamanho corporal em populações naturais de Didelphis (Mammalia: Marsupialia) no sul do Brasil. Revista Brasileira de Biologia, Rio de Janeiro, 59: 461-469.

2001. Food habits, home range and activity of Didelphis aurita (Mammalia, Marsupialia) in southern Brazil. Studies on Neotropical Fauna \& Environment, Lisse, 36: 85-92.

CAJAL, J.L. 1981. Estudios preliminares sobre la area de accion en marsupiales (Mammalia: Marsupialia). Physis C, Buenos Aires, 40: 27-37.

Charles-Dominique, P. 1983. Ecology and social adaptations in didelphid marsupials: comparisons with eutherians of similar ecology, p. 395-422. In: J.F. EIsENberG \& D.G. Kleiman 
(Eds). Advances in the study of mammalian behavior. Philadelphia, American Society of Mammalogist.

Cockburn, A.; M.P. Sсотт \& D.J. Sсоттs. 1985. Inbreeding avoidance and male-biased natal dispersal in Antechinus spp. (Marsupialia: Dasyuridae). Animal Behaviour, London, 33: 908-915.

EMMONS, L.H. \& F. FEER. 1997. Neotropical rainforest mammals: A field guide. Chicago, University of Chicago Press, $\mathrm{XVI}+307 \mathrm{p}$.

FLEMING, T.H. 1972. Aspects of the population dynamics of three opossums in the Panama Canal Zone. Journal of Mammalogy, Provo, 53: 619-623.

Foster, R.B. 1982. The seasonal rhythms in fruitfall on Barro Colorado Island, p. 151-172. In: E.G. LeIGH Jr.; A.S. RAND \& D.M. WINDSOR (Eds). The ecology of a tropical forest. Washington, D.C., Smithsonian Institution Press, 480p.

Gentile, R. \& R. Cerqueira. 1995. Movement patterns of five species of small mammals in a Brazilian restinga. Journal of Tropical Ecology, Cambridge, 11: 671-677.

Gentile, R.; P.S. D'andREa \& R. CERQUeIra. 1997. Home ranges of Philander frenata and Akodon cursor in a Brazilian restinga (coastal shrubland). Mastozoología Neotropical, Mendoza, 4: 105-112.

Holmes, D.J. 1991. Social behavior in captive Virginia opossums, Didelphis virginiana. Journal of Mammalogy, Provo, 72 (2): 402-410.

Hossler, R.J; J.B. Mcninch \& J.D. Harder. 1994. Maternal denning behavior and survival of juveniles in opossums in southeastern New York. Journal of Mammalogy, Provo, 75: 60-70.

HunSAKER, D. II. 1977. Ecology of New World marsupials, p. 95156. In: D. HuNSAKER II (Ed.). The biology of marsupials. New York, Academic Press, XV+537p.

JULIEN-LAFERrière, D. 1995. Use of space by the woolly opossum Caluromys philander (Marsupialia, Didelphidae) in French Guiana. Canadian Journal of Zoology, Ottawa, 73: 12801289.

. 1999. Foraging strategies and food partitioning in the neotropical frugivorous mammals Caluromys philander and Potos flavus. Journal of Zoology London, Cambridge, 247: 71-80.

Julien-Laferrière, D. \& M. Atramentowicz. 1990. Feeding and reproduction of three didelphid marsupials in two neotropical forest (French Guiana). Biotropica, Lawrence, 22: 404-415.

KaLfMANN, J.H. 1983. On the definitions and functions of dominance and territoriality. Biological Review, Cambridge, 58: $1-20$.

KReBS, C.J. 1989. Ecological methodology. New York, Harper
\& Row, XII+654p.

KREBS, J.R. \& N.B. DAVIS. 1996. Introdução à ecologia comportamental. São Paulo, Atheneu, XI+420p.

MAACK, R. 1981. Geografia física do Estado do Paraná. Rio de Janeiro, José Olímpio, 450p.

Magnusson, W.E.; A.L. Francisco \& T.M. Sanaiotti. 1995. Home range size and territoriality in Bolomys lasiurus (Rodentia: Muridae) in an Amazonian savanna. Journal of Tropical Ecology, Cambridge, 11: 179-188.

Monteiro-Filho, E.L.A. \& V.S. Dias. 1990. Observações sobre a biologia de Lutreolina crassicaudata (Mammalia: Marsupialia). Revista Brasileira de Biologia, Rio de Janeiro, 50: 393-399.

NitiKMAN, L.Z. \& M.A. MARES. 1987. Ecology of small mammals in a gallery forest of central Brazil. Annals of Carnegie Museum, Pittsburgh, 56: 75-95.

Ostfeld, R.S. 1990. The ecology of territoriality in small mammals. Trends in Ecology and Evolution, Limerick, 5: 411-415.

Pires, A.S. \& F.A.S. Fernandez. 1999. Use of space by the marsupial Micoureus demerarae in small Atlantic Forest fragments in southeastern Brazil. Journal of Tropical Ecology, Cambridge, 15: 279-290.

RYSER, J. 1992. The mating system and male mating success of the Virginia opossum (Didelphis virginiana) in Florida. Journal of Zoology London, Cambridge, 228: 127-139.

-1995. Activity, movement and home range of Virginia opossum (Didelphis virginiana) in Florida. Bulletin of Florida Museum of Natural History, Gainesville, 38: 177194.

Samuel, D.; D.J. Pierce \& E.O. Garton. 1985. Identifying areas of concentrated use within the home range. Journal of Animal Ecology, Oxford, 54: 711-719.

Smithe, N. 1970. Relationships between fruiting seasons and seed dispersal methods in a neotropical forest. American Naturalist, Chicago, 104: 25-35.

SOKAL, R.R. \& F.J. RoHLF. 1995. Biometry: the principles and practice of statistics in biological research. New York, W.H. Freeman, XIX+887p.

Sunquist, M.E.; S.N. Austad \& F. Sunquist. 1987. Movement patterns and home range in the common opossum (Didelphis marsupialis). Journal of Mammalogy, Provo, 68: 173-176.

Tyndale-Biscoe, C.H. \& R.B. Mackenzie. 1976. Reproduction in Didelphis marsupialis and D. albiventris in Colombia. Journal of Mammalogy, Provo, 57: 249-265.

WolfF, J. O. 1993. Why are female small mammals territorial? Oikos, Holmen, 68: 364-370.

ZAR, J.H. 1984. Biostatistical analysis. Englewood Cliffs, Prentice-Hall, XIV+718p.

Received in 10.X..2002; accepted in 01.VI.2003. 